\title{
Approaches about the expression of two MADS-box genes in pear during the seasonal leaf bud-dormancy transitional phases in the subtropical climate
}

\author{
Gabrielle Leivas 1,^ (iD), Elsa Kuhn Klumb² (iD, Valmor João Bianchi² (iD, Robson Ryu Yamamoto³ (iD, \\ Luciano de Amarante $^{1}$ (D) José Francisco Martins Pereira ${ }^{4}$ (D), Flávio Gilberto Herter ${ }^{2}$ (D), Ana Lúcia Soares

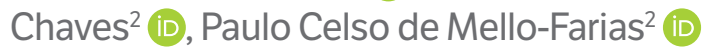 \\ 1. Universidade Federal de Pelotas rợ - Capão do Leão (RS), Brazil. \\ 2. Universidade Federal de Pelotas rớr - Pelotas (RS), Brazil. \\ 3. Universidade Federal de São Carlos Rợ - Centro de Ciências da Natureza - Buri (SP), Brazil. \\ 4. Empresa Brasileira de Pesquisa Agropecuária Rợ - Pelotas (RS), Brazil.
}

Received: Jul. 15, 2021 | Accepted: Nov. 3, 2021

Section Editor: Gabriel Constantino Blain

*Corresponding author: gabrielleleivas@gmail.com

How to cite: Leivas, G., Klum, E. K., Bianch, V. J., Yamamoto, R. R., Amarante, L., Pereira, J. F. M., Herter, F. G., Chaves, A. L. S. Mello-Farias, P. C. (2022). Approaches about the expression of two MADS-box genes in pear during the seasonal leaf bud-dormancy transitional phases in the subtropical climate. Bragantia, 81, e0922. https://doi.org/10.1590/1678-4499.20210211

\begin{abstract}
In the last decades, several biochemical and molecular studies in pear (Pyrus spp.) have revealed processes associated with dormancy establishment and release, leading to the identification of several MADS-box family genes related to bud dormancy regulation. Thus, the aim of this study was to evaluate a preliminary expression pattern of the PpDAM13-1 and PpDAM13-2 MADS-box genes in pear leaf buds (Pyrus pyrifolia Nakai, cultivars Hosui and Nijisseiki; and Pyrus communis L., cultivars Rocha and Santa Maria), grown in the subtropical climate of Southern Brazil. Lateral leaf buds were collected from June to September, and RNA was extracted for evaluation of gene expression by reverse transcription polymerase chain reaction (RT-qPCR). It was found that these two genes decreased the expression as leaf buds are release from dormancy. The Hosui cultivar for both genes and the Nijisseiki cultivar for PpDAM13-2 gene showed peaks of expression in early June, indicating that leaf buds are in a transition dormancy phase. The two European cultivars showed this transition dormancy phase between the end-July and the mid-August. It was concluded that the expression analysis of PpDAM13-1 and PpDAM13-2 genes can be used as a marker to evaluate changes of dormancy phase in pear trees in subtropical climate conditions, and it can be suitable to assist management strategies for overcoming pears' bud dormancy.
\end{abstract}

Key words: Pyrus spp., bud dormancy, warm winter, RT-qPCR, gene expression.

Pears (Pyrus spp.) are grown in different locations around the world. However, the cultivation is not fully developed in Brazil, whose production was 22,108 tons in 2017, which represents about $10 \%$ of the national demand. Moreover, $90 \%$ (189,300 tons) of pears consumed in the country are imported, mainly from Argentina and Portugal (FAO 2019). The high demand for pears in the Brazilian commercial market makes this culture an excellent opportunity for Brazilian growers to diversify fruit production. However, several studies highlight that pears' low production in Brazil is related to the difficulty of managing plants in the field, mainly due to cultivars' climate adaptability.

For survival purpose, temperate perennial plants have characteristics that enable them to suspend and resume growth in response to seasonal and environmental conditions. According to Lloret et al. (2018), the whole succession of events, from the induction of flower buds, suppression and return to growth up to flowering, can be interpreted as a plant defense, which involves a process called dormancy.

There is a straight interaction between environmental and genetic factors which control bud dormancy establishment and release in temperate fruit trees. Therefore, pear production in warmer winter areas, like South of Brazil, is limiting 
because of the lack of sufficient chilling hours induces erratic bud burst, requiring the use of chemicals to stimulate budburst to reduce the negative impact of this environmental condition.

Understanding the molecular and physiological processes underlying bud dormancy in pear and other temperate fruit trees provides greater opportunity to identify the best adapted genotypes to certain cultivation areas and to guide breeding to obtain new genotypes with low chilling requirement.

Estimating the mean time to budburst with the biological method, Bianchi et al. (2000) verified that two Japanese pears (Hosui and Nijisseiki) showed a higher mean time to budburst in April, compared to two Pyrus communis cultivars (Barttlet and Packham's Triumph). This condition was attributed to differences in the correlative inhibition, which affects differentially the dormancy establishment among these cultivars. They also postulated that it is necessary to integrate methods to estimate the chill requirement and the seasonal bud dormancy status in any pear cultivar, especially in warmer winter areas.

Molecular approaches allowed genes identification, including members of the MADS-box family of the MIKC type as possible candidates to regulate dormancy establishment and release, and they are characterized as genes associated with dormancy (Bielenberg et al. 2008). In Japanese pears (Pyrus pyrifolia Nakai), MADS-box genes associated with dormancy (PpMADS13-1 and PpMADS13-2) were isolated by Ubi et al. (2010), and PPMADS13-3 by Saito et al. (2013). In Japanese pears, these genes were up-regulated and down-regulated in leaf buds during endodormancy establishment and release, respectively (Ubi et al. 2010; Saito et al. 2013). It indicates a close relationship between the MADS13 expression pattern and dormancy phase transitions in leaf buds of Japanese pears. The expression pattern presented by these target genes has great potential as a genetic marker to determine dormancy evolution in pear, and it can serve as a basis for gene manipulation that controls dormancy and for orchards management.

Considering the importance of pear cultivation in Brazil, a preliminary study was carried out to evaluate the relative expression of two MADS-Box genes (DAM13-1 and PpDAM13-2), and their potential as marker to identify the establishment and release of seasonal leaf bud-dormancy of four Pyrus spp. cultivars, in warmer winter areas in Southern Brazil.

It was used lateral leaf buds from lateral branches of 21-year-old plants of P. pyrifolia Nakai (Japanese pear) from the cultivars Hosui and Nijisseiki. It was also researched P. communis L. (European pear) of 5-year-old plants, cultivars Rocha

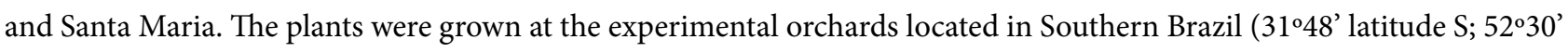
longitude $\mathrm{O} ; 13 \mathrm{~m}$ altitude).

Branches' sections with two or three lateral leaf buds were collected from the lateral and median part of the plant canopy, immediately frozen in liquid nitrogen, and stored at $-80^{\circ} \mathrm{C}$ until RNA extraction. The experimental design was completely randomized with three replicates per cultivar, each one represented by a plant. Bud collections were made in an interval of 25 days between them, from June to September 2018 (June $6^{\text {th }}$, July $3^{\text {rd }}$, July $27^{\text {th }}$, August $20^{\text {th }}$, and September $14^{\text {th }}$ ), totaling five collection dates. Temperatures and precipitation data are shown in Supplementary Figs. 1a and 1b.

Total RNA was extracted from $200 \mathrm{mg}$ of bud samples, according to Chang et al. (1993). RNA concentration and purity were measured in NanoDrop ND-1000, and quality and integrity were verified by an electrophoresis, using $1 \%$ agarose gel. cDNA was synthesized using $1.5 \mu$ g of total RNA, with the GoScript ${ }^{\mathrm{TM}}$ Reverse Transcription Mix kit (Promega ${ }^{\circledR}$ ) in a reaction using random primers with $20 \mu \mathrm{L}$ of final volume.

In this study, $P p D A M 13-1$ and $P p D A M 13-2$ genes were evaluated (primers sequences are shown in Supplementary Table 1). The total volume of reverse transcription polymerase chain reaction (RT-qPCR) was $12 \mu \mathrm{L}$, with $6.25 \mu \mathrm{L}$ of GoTaq ${ }^{\circledR}$ qPCR Master Mix (Promega $\left.{ }^{\circledR}\right), 0.25 \mu \mathrm{L}(10 \mu \mathrm{M})$ of each primer (forward and reverse), $1 \mu \mathrm{L}$ of cDNA (in 1:5 dilution, previously tested and determined), $4.15 \mu \mathrm{L}$ of ultrapure water and $0.1 \mu \mathrm{L}$ of CXR reference dye. Amplification was standardized in CFX-96 Real Time Thermal Cycler (Bio-Rad) equipment. Three replicates were used for each collection time from each cultivar.

Based on the quantification cycle (Cq), specific to each studied primer and cultivar, the collection date that showed higher Cq values was determined as the standard control, so the fifth collection (9/14) was used as a control (RQ=1). The values of relative quantification of expression (RQ) were calculated by Eq. 1 (Livak and Schmittgen 2001):

$$
\mathrm{RQ}=2^{\wedge}(\Delta \Delta \mathrm{Ct})
$$

Actin was used as a housekeeping gene for the reaction, according to Ubi et al. (2010). 
Primer specificity was assessed by a melting curve, from the polymerase chain reaction (PCR) products strands (Supplementary Fig. 2). PCR efficiency (E) was obtained from four serial dilutions of cDNA (1:1; 1:5; 1:25; and 1:125), generating a standard curve for each primer pair. The value of $E$ was estimated by Eq. 2 (Rasmussen 2001):

$$
\mathrm{E}=10(-1 / \text { slope })
$$

The efficiency values varied between 1.8 and 2.2, which correspond to a reaction efficiency between $90-110 \%$ (Supplementary Table 1).

In this study, the specific expression patterns of $P p D A M 13-1$ and $P p D A M 13-2$ genes were investigated during the dormancy transition stages from four pear cultivars (Fig. 1). The results indicated that the genes were differentially expressed in response to seasonal dormancy transition, during early June to mid-September.

(a)

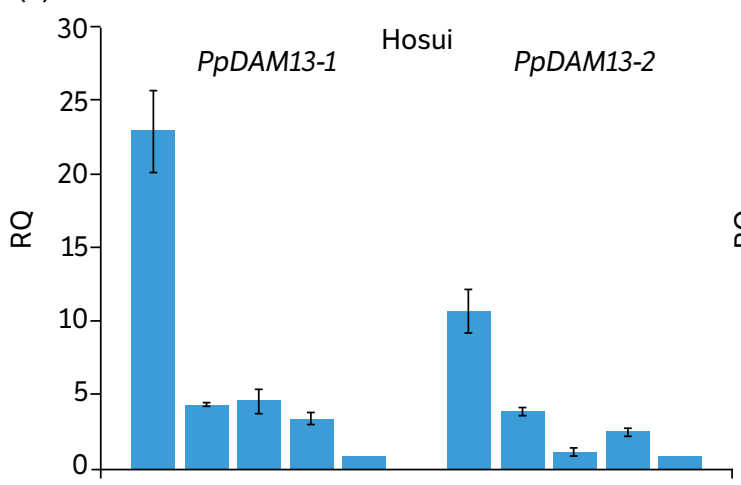

(c)

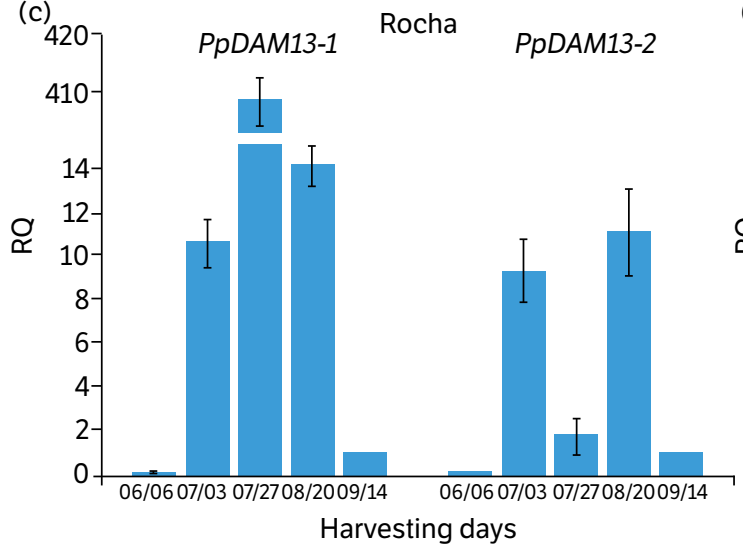

(b)
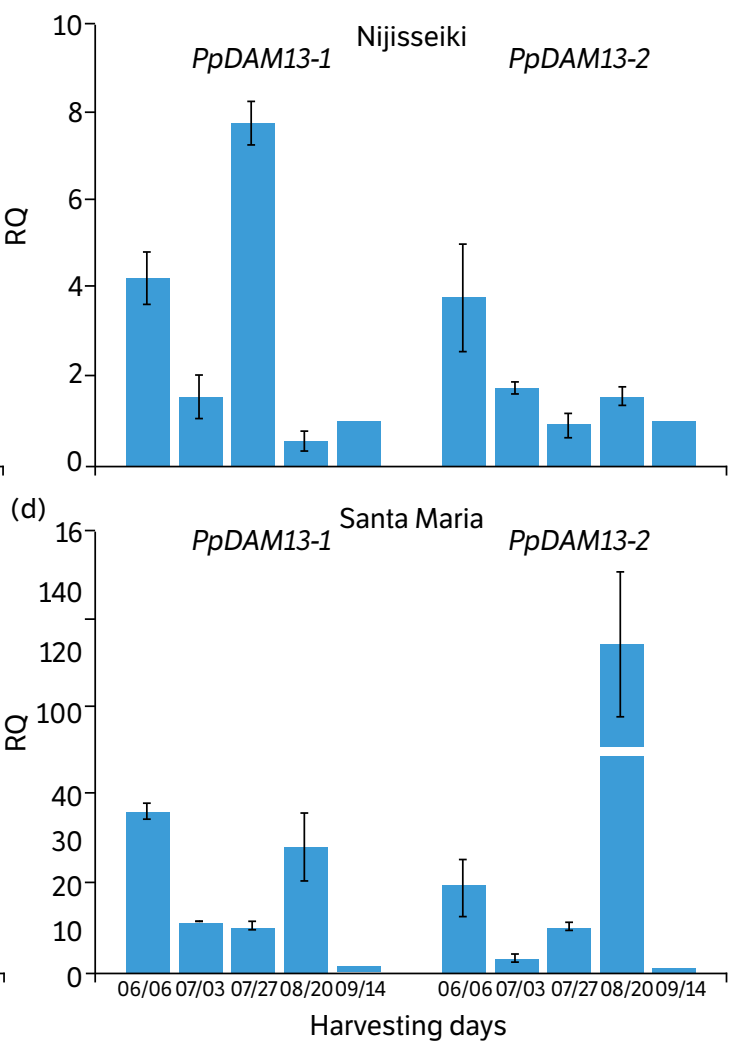

Figure 1. Relative quantification (RQ) of PpDAM13-1 and PpDAM13-2 in lateral branch buds of Pyrus spp. during dormancy period. The dashed line represents the $R Q$ value of the control samples. The bars indicate standard error $(n=3)$.

In relation to cultivar Hosui, both genes showed the highest expression in the first collected samples carried out in early June, with $\mathrm{RQ}=23.01$ and $\mathrm{RQ}=10.77$ for $P p D A M 13-1$ and $P p D A M 13-2$ respectively, followed by a reduction in expression until the last evaluation period (Fig. 1a). For Nijisseiki, the PpDAM13-2 gene showed a similar response to Hosui, but with slightly lower expression values ( $\mathrm{RQ}=3.82$ in the first evaluation time) (Fig. 1b). The PpDAM13-1 gene showed fluctuation in its expression levels, but there was an increase in the RQ values of approximately $50 \%$ between the first and the third evaluation period, followed by a reduction in its expression, which reached the lowest RQ value (1.62) in the last evaluation time (Fig. 1b).

Rocha showed the highest expression value for $P P D A M 13-1$ gene in relation to the other cultivars, that occurred in the third collection period $(\mathrm{RQ}=412.45)$, followed by a decrease in the August collection time (Fig. 1c). For PpDAM13-2 gene, fluctuations in its expression values occurred, that started to be up-regulated from the second collection period (July $3^{\text {rd }}$ ). 
However, a drastic decrease could be observed in expression at the end of July, as well as subsequently an increase in August, characterizing a greater fluctuation in the expression levels of this gene among the evaluated periods (Fig. 1c).

In Santa Maria cultivar, whose chill requirement to dormancy release is slightly high than Nijisseiki's, the expression values of PPDAM13-1 gene were higher in the first and last evaluation period, $\mathrm{RQ}=37.5$ and $\mathrm{RQ}=29.22$, respectively, with $\mathrm{RQ}$ values close to 10 in the intermediate collection times (Fig. 1D). This fluctuation in the expression pattern was also registered for PpDAM13-2 gene, which had a $\mathrm{RQ}=19.79$ in the first evaluation period. It was followed by a reduction in the transcripts identified in the two intermediate collection times, and a peak in the expression values was registered in the last evaluation period (RQ=123.36) (Fig. 1d).

Investigations have characterized genes' responses in vegetative and reproductive buds, whose expression was up regulated during the dormancy establishment and followed by a reduction of expression during dormancy release. These responses were also related to temperature decreases in autumn and the chilling hour accumulation to release endodormancy in different species of Prunus, Pyrus and Malus (Ubi et al. 2010; Yamane et al. 2011; Saito et al. 2013; Kitamura et al. 2016; Wu et al. 2017).

In our study, pear plants experienced temperatures near $15^{\circ} \mathrm{C}$ in April, and gradual temperature reductions, below $15^{\circ} \mathrm{C}$, from the mid-May. Chill accumulation below $7.2^{\circ} \mathrm{C}$ was $20,106,41$ and 40 hours, from the first bud collection date (June $6^{\text {th }}$ ) to the last evaluation in September, respectively, totaling 207 hours. Even with some fluctuation in gene expression values, the four cultivars showed peaks of expression compatible with their chilling requirements to the dormancy release, similarly to the ones registered by Yamane et al. (2011), regarding the DAM5 and DAM6 genes for peach cultivars.

Among the evaluated cultivars, Hosui has the lowest chilling requirement and it was the one that showed a similar expression pattern for both genes. It has the highest $\mathrm{RQ}$ values in the first evaluation period, $P p D A M 13-1(\mathrm{RQ}=23)$ and $P p D A M 13-2(\mathrm{RQ}=10.78)$, with a reduction until the last time. It suggests that, in the first evaluation period, leaf buds of Hosui had already reached a state the dormancy. When comparing the expression patterns of these genes with those from Kosui evaluated by Ubi et al. (2010) and Saito et al. (2013), the highest expression values for both genes appeared. It was obtained on June $6^{\text {th }}$ in Hosui, corresponding to the obtained expression peak in Kosui evaluated on December $9^{\text {th }}$. Hosui leaf buds developed very fast their state of dormancy even in warm winter areas. Bianchi et al. (2000) demonstrated that isolated leaf buds from two cultivars of Japanese pear (Hosui and Nijisseiki) showed deeper dormancy state in late April than the two P. communis cultivars (Barttlet and Packham's Triumph). When analyzing together, these results show that the gradually decrease in the relative expression of the two genes in Hosui correspond to dormancy release phase, under the respective evaluated conditions, although there is a limited chill accumulation in the respective year.

The cultivar Nijisseiki requires a slightly higher chilling accumulation than Hosui, but the expression values were lower than this cultivar. Nijisseiki presented reduction in the relative expression of both genes from June $6^{\text {th }}$ to July $3^{\text {rd }}$, in the third evaluation period (July $27^{\text {th }}$ ), and $P p D A M 13-1$ gene was up regulated $\left(\mathrm{RQ}=8\right.$ ) to level up to the first period (June $6^{\text {th }}$ - RQ 4). Except for the low relative expression of $P p D A M 13-1$, this gene reaches a peak of expression later (July $27^{\text {th }}$ ), that corresponds to the end of dormancy establishment phase, and it agrees with the high chill requirement compared with Hosui.

In another hand, these results suggest the environmental conditions (temperature and precipitation) experienced by Nijisseiki in warmer winter area were not sufficient to up regulate the PpDAM13-2 during dormancy establishment at similar levels of Hosui. However, a more detailed analysis needs to be conducted to elucidate if $P p D A M 13-2$ is not up-regulated in an early period from that evaluated in this study. Because of such environmental conditions, we have registered the beginning of sprouting on September $14^{\text {th }}$ in both Asian pear cultivars (data not shown), in which the results are compatible with the dormancy release phase also described by Ubi et al. (2010) and Saito et al. (2013).

In European pear (with higher chilling requirements), there was a greater tendency to fluctuate the expression values of PpDAM13-1 and PpDAM13-2 genes, especially for Santa Maria, which showed higher expression values on the first and on the last evaluation day, for both genes. These results are related to temperature fluctuations, typically found in subtropical climate conditions, in Southern Brazil, delaying dormancy establishment. The higher expression values in the first evaluation period in relation to the two subsequent periods suggest that leaf buds received sufficient stimulus to start dormancy release on June 6th. However, with the decrease in temperatures in successive evaluations times, leaf buds show a secondary dormancy establishment (since there was still the presence of leaves in the plants). It evolved to a deeper dormancy, that coincides with a relative expression peak on August 20th, especially for PPDAM13-2 gene. Fluctuations in DAMs gene expression during endodormancy establishment and release were also observed by Prudencio et al. (2018) in almond trees, that showed variations in PpDAM6 gene expression in December and January, with peaks and falls among collection periods. 
The expression pattern of $P p D A M 13-1$ gene in Rocha suggests a consistent response with the establishment and release of dormancy phases, whose expression peak occurred on July $27^{\text {th }}$ and may potentially be a dividing point of the two phases. Thus, evaluating responses from a general perspective, an increase in expression levels is suggested, from the first to the last evaluation period, indicating that European cultivars establish their leaf bud dormancy later than Japanese pears as proposed by Bianchi et al. (2000). They show a dormancy peak between the end of July and the mid-August, in warmer winter areas, with a gradual release after this period. Even with variations in climate and seasons, such results reinforce the existence of a link among changes in dormancy phases with the PpDAM13-1 and PpDAM13-2 genes expressions, as observed in Asian pear trees (Ubi et al. 2010; Saito et al. 2013).

The low hours of chilling accumulation $\left(\leq 7.2^{\circ} \mathrm{C}\right)$ in $2018(207 \mathrm{~h})$, and temperature fluctuations may have influenced the expression levels of both evaluated genes in Nijisseiki and Santa Maria, and the PpDAM13-2 gene in Rocha, mainly until the complete dormancy establishment. Due to high similarity in relative expression of $P p D A M 13-2$ in relation to $P p D A M 13-3$, in Saito et al. (2013), we have decided not to consider the last one in our analysis.

Although this study is a preliminary investigation, more detailed analyses are needed to obtain a clearer relationship among expression levels of such target genes with the different dormancy stages in pear trees. Other target genes involved in the process can be included, as the interaction with transcription factors. Moreover, designing a wider collection period could aim to define a safer molecular marker to assist orchards' management and the genotypes selection to better adapt them to climatic conditions of Southern Brazil.

Based on the analysis carried out, it can be concluded that the expression variation of the two researched genes is consistent with the dormancy stages evolution in the four cultivars, but their expressions vary depending on the cultivar, as $P p D A M 13-1$ is more expressed than $P p D A M 13-2$.

\section{AUTHORS' CONTRIBUTION}

Conceptualization: Leivas, G., Yamamoto, R., Amarante, L., Pereira, J. F. M., Herter, F. G., Chaves, A. L. S. and MelloFarias, P. C.; Methodology: Leivas, G., Klumb, E. K., Bianchi, V. J., Yamamoto, R., Amarante, L., Pereira, J. F. M., Herter, F. G., Chaves, A. L. S. and Mello-Farias, P. C.; Investigation: Leivas, G., Klumb, E. K., Yamamoto, R., Amarante, L., Bianchi, V. J., Pereira, J. F. M., Herter, F. G., Chaves, A. L. S. and Mello-Farias, P. C.; Writing - Original Draft: Leivas, G., Klumb, E. K., Bianchi, V. J., Yamamoto, R., Pereira, J. F. M., Herter, F. G., Chaves, A. L. S. and Mello-Farias, P. C.; Writing - Review and Editing: Leivas, G., Bianchi, V. J., Herter, F. G., Chaves, A. L. S. and Mello-Farias, P. C.; Funding Acquisition: Pereira, J. F. M.; Resources: Bianchi, V. J., Pereira, J. F. M.; Supervision: Bianchi, V. J., Chaves, A. L. S., Herter, F. G. and Mello-Farias, P. C.

\section{DATA AVAILABILITY STATEMENT}

Data will be available upon request.

\section{FUNDING}

Empresa Brasileira de Agropecuária

[https://doi.org/10.13039/501100003046]

Project 02.13.05.006.00.00

Coordenação de Aperfeiçoamento de Pessoal de Nível Superior

[https://doi.org/10.13039/501100002322]

Finance Code 001 


\section{ACKNOWLEDGMENTS}

The authors are thankful to the Department of Botany of the Institute of Biology, of the Universidade Federal de Pelotas, for providing a laboratory infrastructure for the examination of molecules.

\section{REFERENCES}

Bianchi, V. J., Arruda, J. J. P., Casagrande Jr., J. G. and Herter, F. G. (2000). Estudo da paradormência em pereira por meio do método biológico. Revista Brasileira de Fruticultura, 22, 294-296.

Bielenberg, D. G., Wang, Y., Li, Z., Zhebentyayeva, T., Fan, S., Reighard, G. L., Scorza, R. and Abbott, A. G. (2008). Sequencing and annotation of the evergrowing locus in peach (Prunus persica [L.] Batsch) reveals a cluster of six MADS-box transcription factors as candidate genes for regulation of terminal bud formation. Tree Genetics \& Genomes, 4, 495-507. https://doi.org/10.1007/s11295-007-0126-9

Chang, S., Puryear, J. and Cairney, J. (1993). A simple and efficient method for isolating RNA from pine trees. Plant Molecular Biology Reports, 11, 113-116. https://doi.org/10.1007/BF02670468

[FAO] Food and Agriculture Organization of the United Nations. (2019). Trade. FAOSTAT (Accessed Nov. 6 2019). http://www.fao.org/ faostat/en/\#compare

Kitamura, Y., Takeuchi, T., Yamane, H. and Tao, R. (2016). Simultaneous down-regulation of Dormancy-Associated Mads-box6 and SOC1 during dormancy release in Japanese apricot (Prunus mume) flower buds. The Journal of Horticultural Science and Biotechnology, 91, 476-482. https://doi.org/10.1080/14620316.2016.1173524

Livak, K. J. and Schmittgen, T. D. (2001). Analysis of relative gene expression data using real-time quantitative PCR and the 2(-Delta Delta C(T) Method. Methods, 25, 402-408. https://doi.org/10.1006/meth.2001.1262

Lloret, A., Badenes, M. L. and Ríos, G. (2018). Modulation of dormancy and growth responses in reproductive buds of temperate trees. Plant Science. 9, 1368. https://doi.org/10.3389/fpls.2018.01368

Prudencio, A. S., Martínez-Gómez, P. and Dicenta, F. (2018). Evaluation of breaking dormancy, flowering and productivity of extra-late and ultra-late flowering almond cultivars during cold and warm seasons in South-East of Spain. Scientia Horticulturae, 235, 39-46. https://doi.org/10.1016/j.scienta.2018.02.073

Rasmussen, R. (2001). Quantification on the light cycler. In: S. Meuer, C. T. Wittwer and K. Nakagawara (Eds.). Rapid cycle real-time PCR. Methods and Applications. Berlin, Heidelberg: Springer Press, p. 21-34. https://doi.org/10.1007/978-3-642-59524-0 3

Saito, T., Bai, S., Ito, A., Sakamoto, D., Saito, T., Ubi, B. E., Imai, T. and Moriguchi, R. (2013). Expression and genomic structure of the dormancy-associated MADS box genes MADS13 in Japanese pears (Pyrus pyrifolia Nakai) that differ in their chilling requirement for endodormancy release. Tree Physiology, 33, 654-667. https://doi.org/10.1093/treephys/tpt037

Ubi, B. E., Sakamoto, D., Ban, Y., Shimada, T., Ito, A., Nakajima, I., Takemura, Y., Tamura, F., Saito, T. and Moriguchi, T. (2010). Molecular cloning of dormancy-associated mads-box gene homologs and their characterization during seasonal endodormancy transitional phases of Japanese pear. Journal of American Society for Horticultural Science, 135, 174-182. https://doi.org/10.21273/JASHS.135.2.174

Wu, R., Tomes, S., Karunairetnam, S., Tustin, S. D., Hellens, R. P., Allan, A. C., Macknight, R. C. and Varkonyi-Gasic, E. (2017). SVP-like MADS box genes control dormancy and budbreak in apple. Frontiers in Plant Science, 8, 477. https://doi.org/10.3389/fpls.2017.00477

Yamane, H., Ooka, T., Jotatsu, H., Sasaki, R. and Tao, R. (2011). Expression analysis of PpDAM5 and PpDAM6 during flower bud development in peach (Prunus persica). Scientia Horticulturae, 129, 844-848. https://doi.org/10.1016/j.scienta.2011.05.013 


\section{SUPPLEMENTARY MATERIAL}
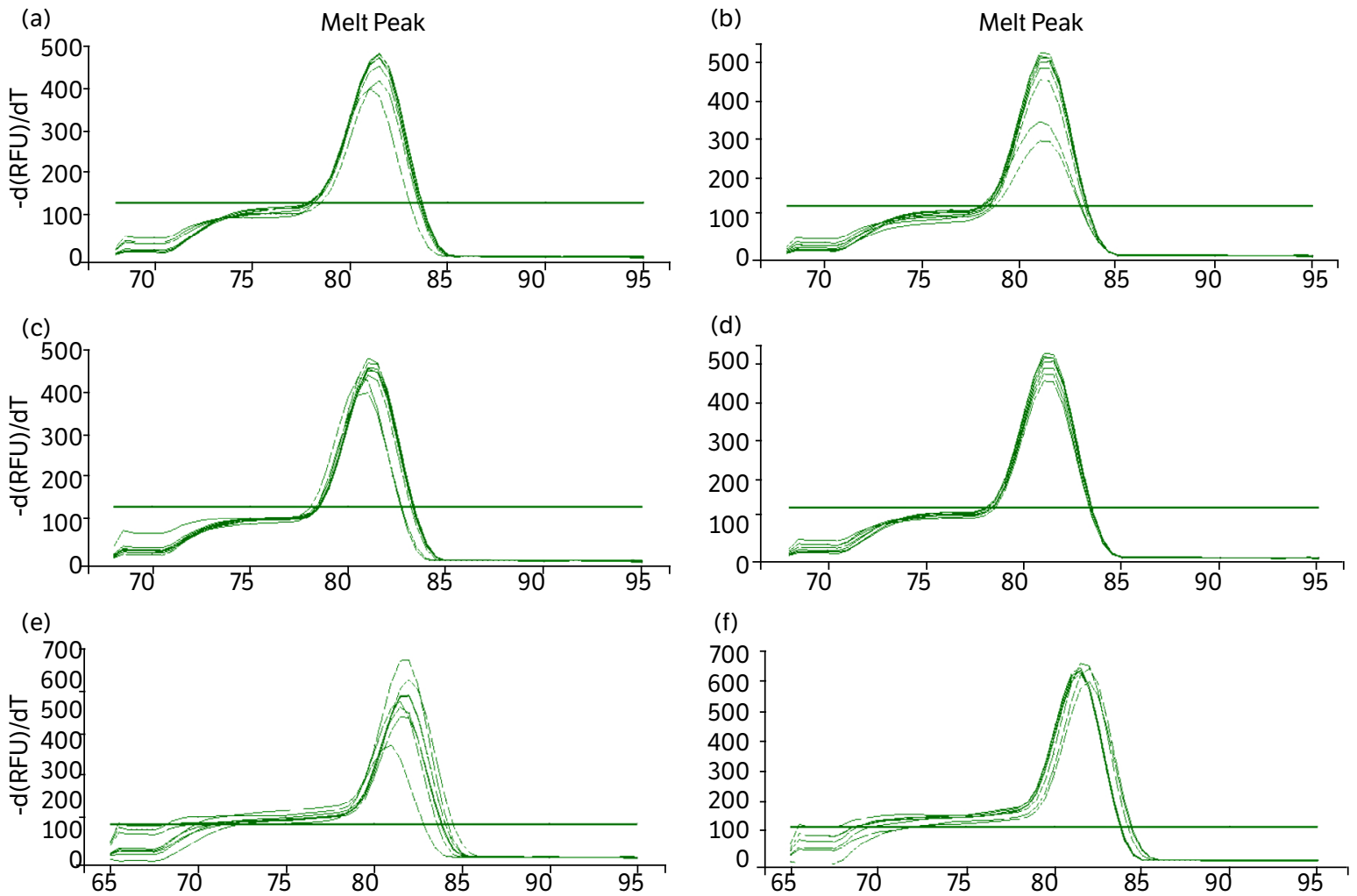

(g)
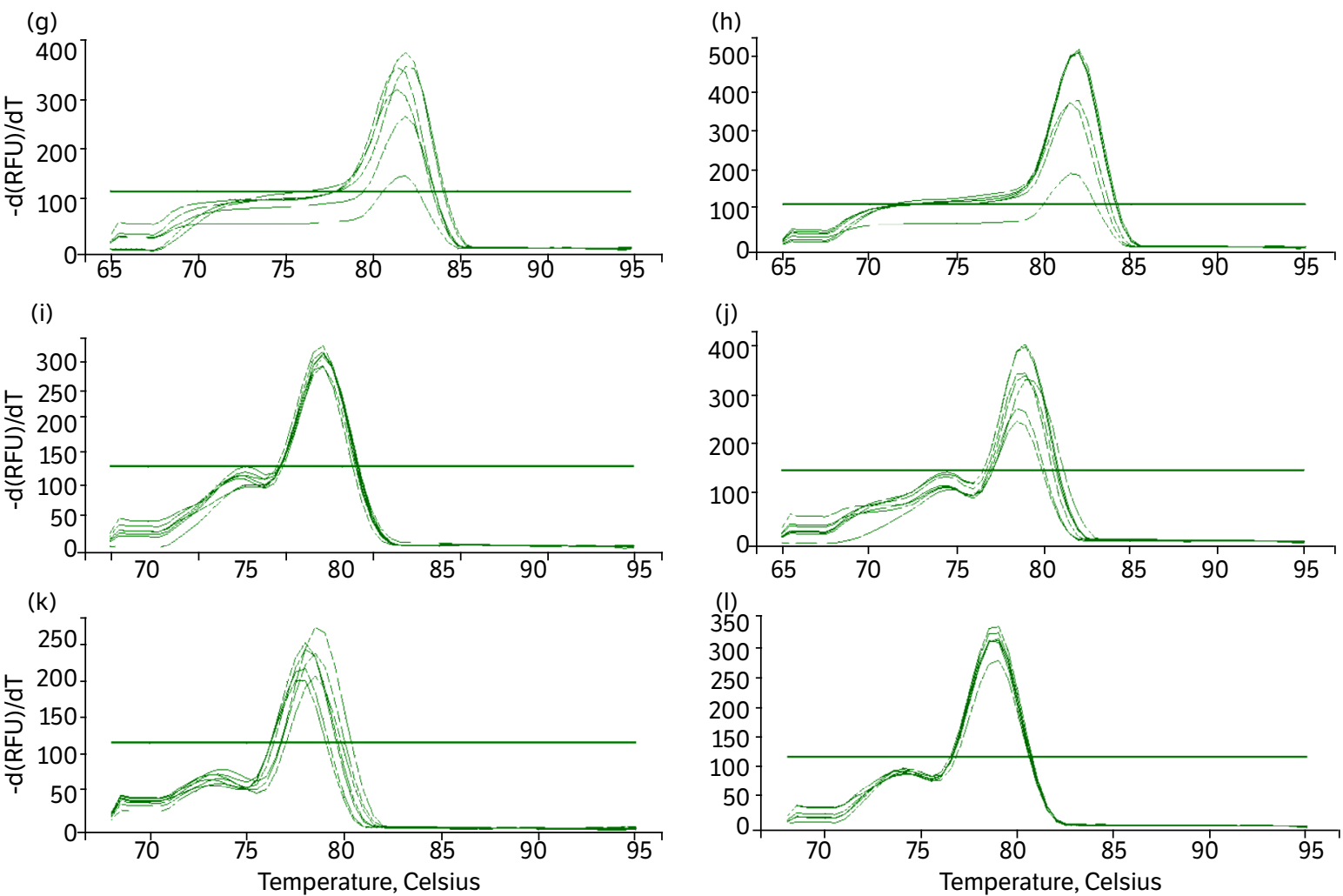

Figure S1. Specificity of the used primers for the genes studied in each cultivar. Melt peak of PpDAM13-1 in the cultivars (a) Housui, (b) Nijisseiki, (c) Rocha, and (d) Santa Maria; melt peak of PpDAM13-2 in the cultivars (e) Housui, (f) Nijisseiki, (g) Rocha, and (h) Santa Maria; melt peak of Actin gene in the cultivars (i) Housui, (j) Nijisseiki, (k) Rocha, and (I) Santa Maria. 
Table S1. Primers sets used in this study and their efficiency in the RT-qPCR analysis.

\begin{tabular}{|c|c|c|c|c|}
\hline Gene & Primer Sequences (F - Forward, R - Reverse) & Cultivar & Efficiency & Reference \\
\hline \multirow{4}{*}{ PpDAM13-1 } & \multirow{4}{*}{$\begin{array}{l}\text { 5'- ACCCACGCTTCATCAGCTACT -3' } \\
\text { 5'- CCAATTTTTCTAACTTCTG TAGTTCACC -3' }\end{array}$} & Housui & 1.94 & \multirow{4}{*}{ Ubi et al. (2010) } \\
\hline & & Nijisseiki & 1.91 & \\
\hline & & Rocha & 2.16 & \\
\hline & & Santa Maria & 1.94 & \\
\hline \multirow{4}{*}{ PpDAM13-2 } & \multirow{4}{*}{$\begin{array}{l}\text { 5'- AAATCACGCTTCACCAACTGC -3' } \\
\text { 5'- CACCAATTTTTCTAACTTGTTCAGTTGATA -3' }\end{array}$} & Housui & 2.07 & \multirow{4}{*}{ Ubi et al. (2010) } \\
\hline & & Nijisseiki & 2.28 & \\
\hline & & Rocha & 1.78 & \\
\hline & & Santa Maria & 1.72 & \\
\hline \multirow{4}{*}{ Actin } & \multirow{4}{*}{$\begin{array}{l}\text { 5'- CAGGCATTCACGAGACCACA -3' } \\
\text { 5'- TGCCAGGAACATGGTAGAA -3' }\end{array}$} & Housui & 2.02 & \multirow{4}{*}{ Ubi et al. (2010 } \\
\hline & & Nijisseiki & 2.22 & \\
\hline & & Rocha & 2.16 & \\
\hline & & Santa Maria & 1.94 & \\
\hline
\end{tabular}

RT-qPCR: reverse transcription polymerase chain reaction.

(a)

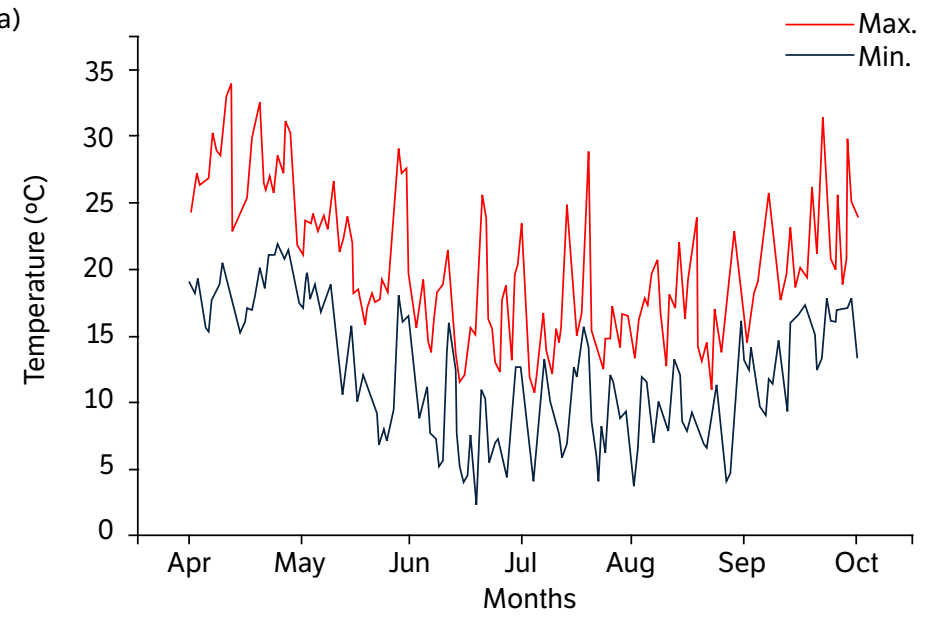

(b)

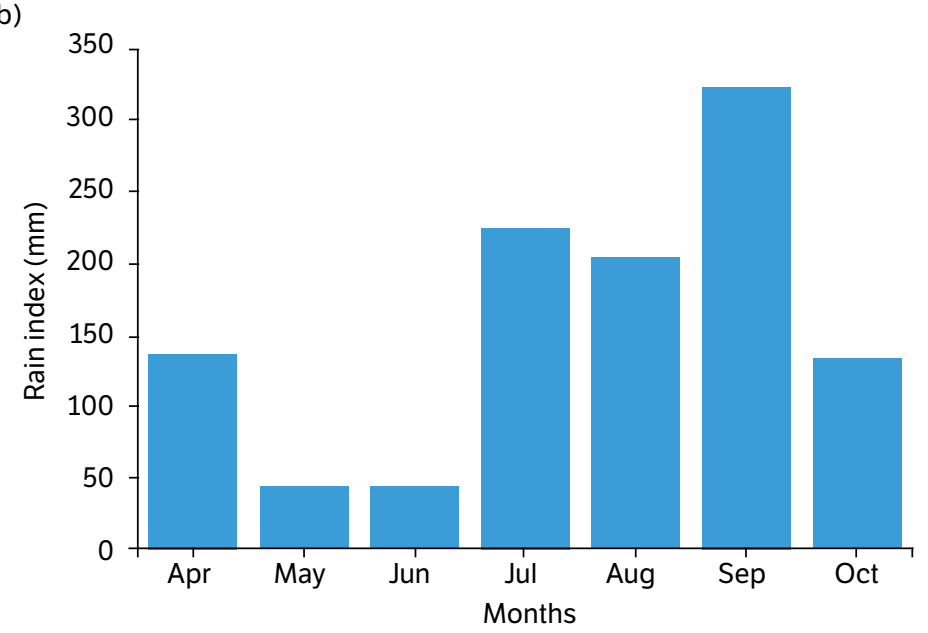

Figure S2. (a) Maximum and minimum temperature recorded from April to October 2018; (b) monthly averages of rainfall from April to October 2018. 